\title{
Kształtowanie miejskich przestrzeni publicznych zgodnie z potrzebami lokalnych społeczności
}

\section{Creating urban public spaces according to local communities needs}

\section{Streszczenie}

W artykule przedstawiono problemy współczesnych miast, które są związane z urbanizacją i nadmiernym rozwojem ruchu samochodowego. Nowe lub rewitalizowane przestrzenie publiczne, jakie powstają w miastach, są często wynikiem współpracy lub nacisków wywieranych przez lokalne społeczności. Nowe realizacje to najczęściej tereny zielone o charakterze rekreacyjnym - tego potrzebują mieszkańcy miast. Inwestycja w tereny zielone o różnej skali i charakterze jest opłacalna dla władz miejskich i inwestorów - podnosi nie tylko jakość życia mieszkańców, ale ma realny ekonomiczny wpływ na wartość nieruchomości i rozwój biznesu.

Słowa kluczowe: miejskie tereny zielone, potrzeby społeczności, projektowanie dla mieszkańców, przestrzenie społeczne w mieście

\begin{abstract}
The article shows problems of modern cities, which are connected with urbanisation and increasing car traffic. New urban public spaces emerges often with coordination or with pressure from local community. New implementations are often recreational green areas - this is the basin need of citizens. Investing in green, in large or small scale, is profitable business for government and investors - it rises quality of human urban life as well as real property value and business development.
\end{abstract}

Keywords: urban greenery, social needs, designing for local community, urban social spaces 


\section{WSTĘP}

Miasta w XX wieku uległy gwałtownym i różnorodnym przekształceniom, które miały wiele różnorodnych przyczyn: rozwój technologii i industrializacja, wydarzenia historyczne, jak wojny światowe wskutek, których prawie całkowicie zniszczonych zostało wiele miast europejskich. Idee modernistyczne, dotyczące funkcjonalnego kształtowania miasta, wcielano w życie zarówno w odbudowywanych po wojnie europejskich ośrodkach miejskich, jak i stale rozwijających się miastach amerykańskich. Powojenny rozwój przemysłu wymusił rozwój dróg i środków transportu, a rozwój motoryzacji i upowszechnienie się indywidualnego ruchu samochodowego doprowadziło do znacznych zmian w strukturze urbanistycznej miast.

Układ komunikacyjny w modernistycznej koncepcji miasta, w której poszczególne funkcje były od siebie odseparowane, odgrywał ważną rolę łącznika pomiędzy poszczególnymi fragmentami XX-wiecznych metropolii ${ }^{1}$. Szybkie, szerokie i wygodne arterie komunikacyjne miały za zadanie ułatwiać ludziom przemieszczanie się pomiędzy strefą zamieszkania a miejscem pracy, nauki czy rozrywki lub wypoczynku. W drugiej połowie XX wieku mieszkańcy krajów Europy Zachodniej i Stanów Zjednoczonych mogli sobie pozwolić na zakup auta dla praktycznie każdej rodziny. Spowodowało to wzrost ilości samochodów na drogach oraz coraz większe zapotrzebowanie na miejsca do ich parkowania. Rozwój komunikacji kołowej spowodował inne negatywne zjawiska: duże zanieczyszczenie powietrza w miastach, hałas, zmniejszenie bezpieczeństwa dla pieszych itp. Również układ urbanistyczny wielu miast niekorzystnie się zmienił, został poprzecinany arteriami komunikacyjnymi, które podzieliły przestrzeń dawnych dzielnic miejskich, nie wchodząc w żadne związki z zabudową. Wielopasmowe drogi prowadzono często na estakadach ponad budynkami, prawie zawsze bez żadnego towarzyszącego im ruchu pieszego. Odbudowywane po zniszczeniach wojennych miasta europejskie zyskiwały zupełnie nowe układy komunikacyjne, projektowane zgodnie z ideami ówczesnych czasów, segregującymi ruch pieszy od kołowego i nadającymi priorytet komunikacji samochodowej ${ }^{2}$. Ówczesne miasta amerykańskie również podążały w tym kierunku, ale tam rozwój układów komunikacyjnych był skutkiem rozległej struktury przestrzennej oraz odmiennego charakteru zabudowy mieszkaniowej. Rozlewające się przedmieścia z jednorodzinnymi domami musiały być dobrze skomunikowane z centrum miasta, a odległości, jakie przy tym były pokonywane, nie dawały dobrych szans na rozwój komunikacji zbiorowej w wielu miastach Stanów Zjednoczonych ${ }^{3}$.

Samochody i rozwój układu komunikacyjnego były jednym z wielu elementów urbanizacji, ale można stwierdzić, że najbardziej bezpośrednio wpłynęły na jakość życia mieszkańców miast. Zastawione samochodami chodniki, zatłoczone ulice, hałas i spaliny zaczęły być coraz bardziej uciążliwe dla ludzi i nie przynosiły prognozowanych korzyści. Te negatywne zjawiska zaczęły wywoływać dyskusje w społeczeństwach poszczególnych krajów, a stosowane rozwiązania urbanistyczne coraz częściej poddawano krytyce. 
W 1961 roku Jane Jacobs opublikowała książkę Śmierć i życie wielkich miast Ameryki, która według autorki była atakiem na ówcześnie obowiązujące metody projektowania miast [4, s. 193]. Publikacja była efektem doświadczeń pisarki, mieszkanki Nowego Jorku, która wraz z lokalną społecznością wystąpiła przeciwko przebudowie dzielnicy Greenvich Village. Według koncepcji władz dzielnica miała być przebudowana zgodnie z ideami Le Corbusiera: szerokie i proste estakady drogowe miały przecinać ten fragment miasta, a pośród zieleni powstałyby wysokie punktowce dla dawnych mieszkańców ${ }^{4}$. Lokalna społeczność Greenvich Village podniosła bunt, ponieważ ich dzielnica była dobrze zorganizowanym i żyjącym fragmentem miasta z wieloma parkami, lokalnymi sklepami i bezpiecznymi ulicami. Publiczne protesty, spotkania z projektantami oraz naciski na władze miejskie doprowadziły do szerokiej debaty na temat kształtu urbanistycznego Nowego Jorku i przyszłości innych jego dzielnic. Na skutek szeroko zakrojonej akcji społecznej, do której zaangażowano również media, udało się obronić dzielnicę przed przebudową, a lokalną społeczność przed wysiedleniami. Była to jedna z pierwszych akcji przeprowadzonych z sukcesem przez lokalną społeczność, która stała się impulsem do podobnych działań dla innych mieszkańców miast. Jane Jacobs pisała: „Od największej nawet brzydoty i bałaganu gorszy jest fałszywy ład, wprowadzony bez poszanowania lub kosztem prawdziwego porządku miasta, które walczy o przetrwanie i poszanowanie”5. Była to charakterystyka ówcześnie prowadzonej „rewitalizacji” obszarów miejskich, w której priorytety zyskiwały szybkie trasy komunikacyjne bez uwzględnienia jakichkolwiek potrzeb lokalnej społeczności.

\section{MIEJSKIE PRZESTRZENIE PUBLICZNE ZAPROJEKTOWANE PRZY WSPÓŁUDZIALE LOKALNYCH SPOŁECZNOŚCI}

Obecnie, kiedy zdefiniowano i spopularyzowano idee zrównoważonego rozwoju i zrównoważonego projektowania, głos społeczności, dotyczący kształtu przestrzeni miejskiej, staje się coraz ważniejszy. Wzrost świadomości społecznej, dotyczący dobrych warunków do życia w mieście, spowodował, że różne formalne i nieformalne grupy społeczne uczestniczą często w procesie projektowania nowych przestrzeni publicznych. W okresie ostatnich kilkudziesięciu lat powstało wiele nowych realizacji, dostosowanych do potrzeb lokalnej społeczności. Warto tu zwrócić szczególną uwagę na rewitalizacje miejskich przestrzeni publicznych z dwóch powodów: przywracają one stan sprzed okresu dominacji ruchu kołowego oraz pokazują, czego tak naprawdę brak w obecnym stanie przestrzeni miejskiej.

\subsection{HEINER-METZGER PLAZA, NEU ULM}

Heiner-Metzger Plaza przez wiele lat służył jako plac dla samochodów przed dworcem kolejowym. Miejsce było chętnie wykorzystywane na parking, ponieważ Neu Ulm posiadało szybkie połączenia kolejowe z pobliskim większym miastem, do którego mieszkańcy 
dojeżdżali do pracy. Na początku XXI wieku miasto podjęło decyzję o rehabilitacji części śródmieścia, która miała na celu połączenie kompozycyjne i funkcjonalne Neu Ulm z przebiegającym obok niego Dunajem 6 . Przebudowa placu przed dworcem stała się jedną z części tego projektu, a przeniesienie parkingu do części podziemnej dało szansę na stworzenie nowej atrakcyjnej przestrzeni publicznej w centrum miasta. Z inicjatywy burmistrza do procesu projektowego zaangażowano oprócz architektów również lokalną społeczność. Celem tej współpracy było stworzenie programu zagospodarowania dla placu, a wiodącą wytyczną było hasło: „Miejsce spotkań dla różnych pokoleń” i „Przestrzeń do zabawy”7. Urząd miejski zorganizował cykl warsztatów, w których uczestniczyła młodzież szkolna i projektanci z biura Atelier Dreiseitl, którzy wypracowali propozycje różnych rozwiązań do przedstawienia lokalnej społeczności. W trakcie warsztatów wymyślono miejsca do rekreacji: szachy, ściankę wspinaczkową, stół z piłkarzykami oraz niewielki zbiornik wodny przeznaczony do zabawy. Efektem tej współpracy był projekt, w którym znajdowały się różne strefy rekreacyjne rozmieszczone na placu oraz miejsca do odpoczynku pod drzewami. Zaprojektowano także założenie wodne o charakterze rekreacyjnym i estetycznym jako nowy punkt orientacyjny w mieście. Ważnym aspektem w zagospodarowaniu placu było zastosowanie zasad zrównoważonego projektowania. Założenie wodne jest częścią systemu zagospodarowania wód opadowych SUDS ${ }^{8}$ - woda jest gromadzona, oczyszczana, a następnie ponownie wykorzystywana do zasilania fontanny.

W trakcie budowy do działania zostały zaangażowane również lokalne firmy, które podarowały część materiałów budowlanych. Projekt, który odpowiadał potrzebom lokalnej społeczności, i zaangażowanie różnych grup społecznych w proces powstawania Heiner-Metzger Plaza sprawiło, że powstało miejsce, z którego chętnie korzystają mieszkańcy, ale też estetycznie wykonane, z unikalnymi formami przestrzennymi. Sukces Heiner-Metzger Plaza stał się sukcesem wszystkich, mimo że inwestorem było miasto i to od władz miejskich wyszedł impuls do zaproszenia społeczności o współdecydowaniu o kształcie i formie przestrzeni publicznej w mieście. Heiner-Metzger Plaza jest placem znajdującym się w śródmieściu - mógłby pozostać przestrzenią reprezentacyjną przed dworcem kolejowym, jednak mieszkańcy wskazali inne zagospodarowanie dla tego obszaru, nadając mu funkcję rekreacyjną w otoczeniu zieleni i wody, co nie jest częstym rozwiązaniem funkcjonalnym dla głównych miejskich placów.

\subsection{HIGH LANE PARK, NOWY JORK}

High Lane Park w przeciwieństwie do powyżej opisywanej realizacji powstał jako oddolna inicjatywa - jest efektem zaangażowania lokalnych miejskich aktywistów oraz społeczności. Jest to park nietypowy, powstał na zniszczonym i zdegradowanym terenie nieczynnej kolei towarowej, przebiegającej na estakadzie pomiędzy budynkami przez kilkanaście przecznic Manhattanu. Kolej była wykorzystywana do lat 80. XX wieku, jednak wskutek rozwoju 
transportu drogowego stała się nierentowna i ją zamknięto ${ }^{9}$. Przez prawie 20 lat cała infrastruktura niszczała, zarastała zielenią i została zasiedlona przez ptaki. W 1999 roku High Lane została przeznaczona do rozbiórki, jednak działacze lokalnej organizacji Friends of the High Lane ${ }^{10}$ podjęli próbę ocalenia starej linii kolejowej i przekształcenia jej w miejską przestrzeń publiczną ${ }^{11}$. Działacze, mimo oporu burmistrza Nowego Jorku i właścicieli gruntów pod kolejką oraz deweloperów, podjęli próbę stworzenia projektu zagospodarowania dla tej przestrzeni. Do projektu zostało zaangażowanych wiele osób: artystów, projektantów oraz zwykłych obywateli. Rozpoczęta została kampania społeczna na rzecz ocalenia High Lane - drukowano ulotki i broszury, publikowano artykuły i wykorzystywano Internet do rozpowszechnienia tej idei.

Po dwóch latach udało się unieważnić decyzję o rozbiórce, a następnie został ogłoszony konkurs na zagospodarowanie wiaduktu. Nadrzędną ideą w projekcie tego parku było zachowanie jego surowej natury, która przez 20 lat, kiedy wiadukt niszczał, objęła w posiadanie ten teren. Konieczne było również zachowanie samej struktury kolejki, która na estakadzie wije się pomiędzy budynkami. Ten unikalny pomysł na stworzenie parku ponad poziomem terenu, którego kształt jest dość nietypowy, okazał się dużym sukcesem. Kolejne odcinki parku oddawano do użytku w latach 2009, 2011 i 2014. Inwestycja została częściowo sfinansowana przez władze Nowego Jorku, mieszkańców oraz fundację Friends of the High Lane [12]. Od samego otwarcia parku stał się on jedną z ciekawszych miejskich atrakcji - to przede wszystkim zasługa koncepcji zagospodarowania, która łączy elementy starej, zdegradowanej infrastruktury z zielenią oraz małą architekturą i obiektami sztuki. High Lane Park jest też żyjącą przestrzenią społeczną - fundacja, która opiekuje się parkiem organizuje warsztaty przyrodnicze i edukacyjne, koncerty, wydarzenia artystyczne, gry i zabawy dla dzieci, ćwiczenia w plenerze itd. ${ }^{13}$. Nowy Jork zyskał nową atrakcyjną przestrzeń publiczną, ale jej pojawienie się pociągnęło za sobą również inne zjawiska. Nieruchomości dookoła High Lane Park znacznie zyskały na wartości, w okolicy zaczął otwierać się biznes: sklepy, restauracje, galerie itd. Dookoła zaczęły powstawać nowe budynki mieszkalne, a miejsce to jest również chętnie odwiedzane przez turystów. Władze miejskie, mimo początkowego oporu, zaangażowały się w inwestycję High Lane Park. Oddolna inicjatywa i oryginalny pomysł kilku miejskich aktywistów stał się impulsem do ożywienia części miasta i sukcesu ekonomicznego dla wielu podmiotów.

\section{WSPÓŁPRACA Z LOKALNYMI SPOŁECZNOŚCIAMI W POLSKICH MIASTACH}

W Polsce działalność różnego rodzaju miejskich ruchów społecznych ze względów politycznych możliwa była dopiero od lat 90. XX wieku. Początkowo w większych miastach działania z lokalną społecznością inspirowane były przez artystów, takich jak np. Paweł Althamer. Tworzył on z mieszkańcami warszawskiego Bródna m.in. instalacje „Bródno 2000”14 oraz 
park rzeźby na Bródnie. Największy odzew wśród mieszkańców Warszawy wywołała instalacja Joanny Rajkowskiej „Dotleniacz”, która powstała na placu Grzybowskim w 2007 roku. Na zielonym terenie placu w okresie letnim na kilka miesięcy zbudowano zbiornik wodny obsadzony zielenią i zaopatrzony w specjalne urządzenie wytwarzające mgłę i ozonujące powietrze. Dookoła na zieleńcu rozmieszczono miejsca do siedzenia i odpoczynku. Miejsce stało się tak bardzo popularne wśród okolicznych mieszkańców, że po kilku miesiącach pojawiły się głosy, aby zostawić instalację na stałe. Z inicjatywy społecznej zaczęto nawet zbierać podpisy o utrzymanie „Dotleniacza”, co z kolei wywołało sprzeciw władz miasta przeciwko takim działaniom ${ }^{15}$. Instalacja została rozebrana, ale dzięki niej ludzie zaczęli zdawać sobie sprawę, że mogą mieć jakiś głos w sprawie kształtu przestrzeni publicznej, która ich otacza. Okazało się, że wśród mieszkańców miasta istnieje potrzeba kontaktu z przyrodą, naturą, a sukces „Dotleniacza” uświadomił wszystkim, że często w mieście brak jest takich właśnie miejsc.

W Polsce ciągle jeszcze miejskie inicjatywy społeczne to domena wielkich miast, takich jak Warszawa, Kraków, Wrocław itd., w których prężnie działają miejscy aktywiści oraz różnorodne organizacje społeczne. Wydaje się, że jesteśmy społeczeństwem słabo angażującym się w różnorodne działania na rzecz przestrzeni miejskiej. Z drugiej strony władze często traktują konsultacje społeczne jako „zło konieczne” i ograniczają je do niezbędnego minimum. Czas, który miały społeczeństwa Europy Zachodniej czy Stanów Zjednoczonych, aby dojrzeć do świadomości o współdecydowaniu o przestrzeni publicznej swoich miast, to kilkadziesiąt ostatnich lat.

Od kilku lat w niektórych polskich miastach wprowadzany jest budżet partycypacyjny, zarówno w dużych ośrodkach, jak i w małych miastach, takich jak np. Przemyśl. Ten pomysł na finansowanie projektów w przestrzeni publicznej, przeznaczonych dla mieszkańców miast, powstał w latach 90. XX wieku w Porto Allegre w Brazylii. Władze miasta pozwoliły tam mieszkańcom współdecydować o inwestycjach przeznaczonych dla całego miasta oraz poszczególnych dzielnic ${ }^{16}$. Z czasem ten sposób finansowania spopularyzował się w wielu krajach, jednak w Polsce na projekty z budżetu obywatelskiego przeznacza się ok. 1\% budżetu miejskiego. Pomimo że projekty w budżecie obywatelskim są często działaniami doraźnymi i nie wpisują się w szerszą politykę kształtowania przestrzeni publicznej przez władze samorządowe, to na podstawie zgłaszanych i wygranych projektów można zauważyć, jakie są najważniejsze potrzeby ich mieszkańców.

W Krakowie na budżet obywatelski mieszkańcy mogą głosować od 2014 roku. Są to zadania w zakresie ogólnomiejskim oraz przeznaczone dla poszczególnych dzielnic miasta. Niestety, pomimo wielu projektów frekwencja średnio wynosi ok. 7\%. Cztery ostatnie edycje krakowskiego budżetu obywatelskiego przyniosły wiele zgłoszonych projektów, z których większość została zrealizowana. Na przestrzeni ostatnich kilku lat widać, że coraz więcej projektów, wybranych przez mieszkańców do realizacji, dotyczy utworzenia lub ulepszenia istniejących terenów zielonych i terenów przeznaczonych do odpoczynku i rekreacji. Jeszcze 
w 2014 roku na 14 zadań ogólnomiejskich przeznaczonych do realizacji tylko trzy związane były z terenami zielonymi i rekreacją. W 2017 roku na 19 wybranych projektów przeznaczonych do realizacji już 12 dotyczy terenów zielonych - jest to m.in. budowa nowych parków i rozbudowa infrastruktury rekreacyjnej na istniejących terenach zielonych, zagospodarowanie miejskiego kąpieliska oraz sadzenie drzew w poszczególnych dzielnicach ${ }^{17}$.

Taki wzrost wybieranych przez mieszkańców Krakowa w budżecie obywatelskim projektów, dotyczących zwiększenia ilości terenów zielonych, na pewno wiąże się ze zwiększeniem świadomości społecznej w zakresie jakości życia w mieście z tak zanieczyszczonym powietrzem jak Kraków. Z drugiej strony miasto intensywnie zabudowuje się nowymi inwestycjami mieszkaniowymi i biurowymi bez znaczących nakładów na zwiększanie terenów zielonych. Dopiero w 2015 roku w Krakowie powołany został Zarząd Zieleni Miejskiej, który ma za zadanie zarządzanie i prowadzenie inwestycji związanych z zielenią publiczną. Jak ważne są takie tereny dla mieszkańców miasta, można zauważyć nie tylko obserwując wyłonione w plebiscycie projekty budżetu obywatelskiego. Na podstawie ankiet przeprowadzonych przez firmę Obido dla 45\% ankietowanych osób podczas wybierania mieszkania bardzo ważna jest bliskość zieleni, parków i terenów rekreacyjnych i są gotowi więcej zapłacić za nieruchomość, która spełnia to kryterium ${ }^{18}$.

\section{PODSUMOWANIE}

W tekście przedstawiono różne sposoby wpływania społeczności na kształt przestrzeni publicznej w miastach. Przy współudziale władz lub wręcz przeciwnie - w wyniku oddolnej inicjatywy społecznej w miastach powstają założenia odpowiadające potrzebom lokalnych społeczności. Te potrzeby są niezmienne w czasie - obejmują najczęściej szeroko dostępne miejsca przeznaczone dla rekreacji i wypełnione zielenią lub wodą. Mieszkańcy nie postulują o budowę nowych galerii handlowych, biurowców i innych komercyjnych obiektów, ale o miejsca, gdzie mogliby spędzać wolny czas, wypoczywać, nawiązywać relacje sąsiedzkie, czuć się bezpiecznie. Dziś widać, że warto zwracać uwagę na inicjatywy społeczne. Dzięki nim nowe przestrzenie publiczne to najczęściej miejsca z terenami zielonymi i rekreacyjnymi. To pokazuje nam, jakie są współcześnie potrzeby ludzi żyjących w miastach i czego im najczęściej brakuje. Oddolne inicjatywy mogą również przynieść korzyści zarówno władzom miejskim, jak i prywatnym inwestorom. Zielone tereny rekreacyjne to atrakcyjne miejsca gromadzące lokalne społeczności, które podnoszą wartość nieruchomości i działek w ich pobliżu. Jak pokazują różne badania, ludzie poszukują takich mieszkań. Dodatkowo atrakcyjne zielone tereny rekreacyjne mogą stać się katalizatorem zmian dla najbliższego otoczenia - nowych sklepów, restauracji, kawiarni, zaplecza usługowego dla terenów zielonych itp. 


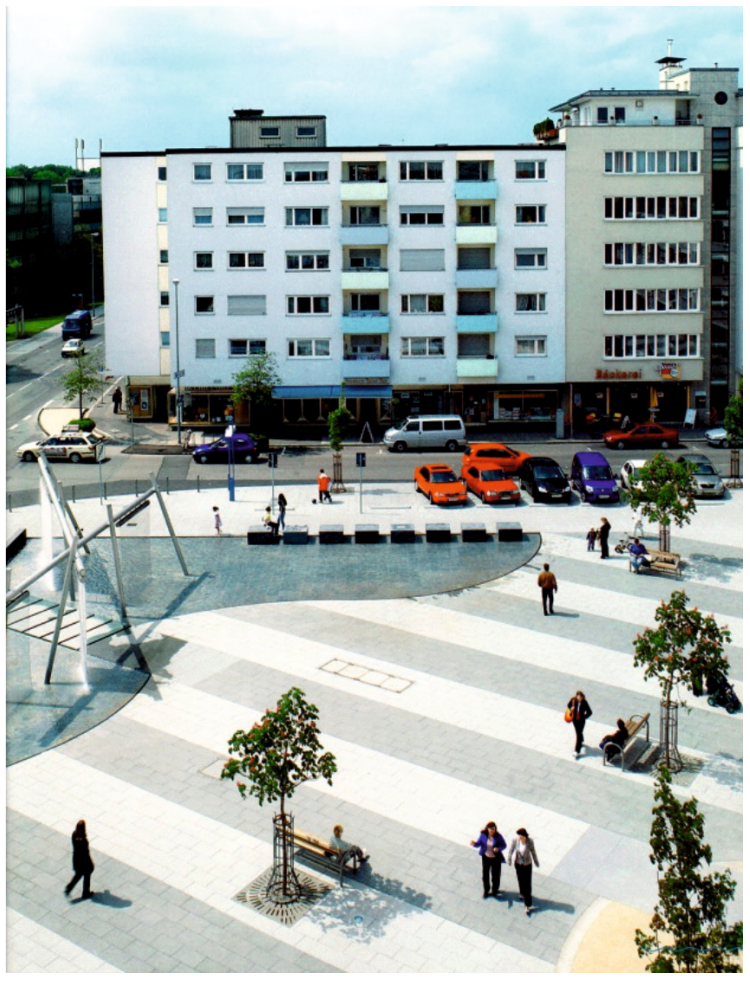

II. 1. Zagospodarowanie przestrzenne Heiner-Metzger Plaza w Neu Ulm (źródło: Dreiseitl H., Grau D., New waterscapes. Planning, Building and Designing with Water, Birkhauser, Basel 2005)

III. 1. Development of Heiner-Metzger Plaza in Neu Ulm

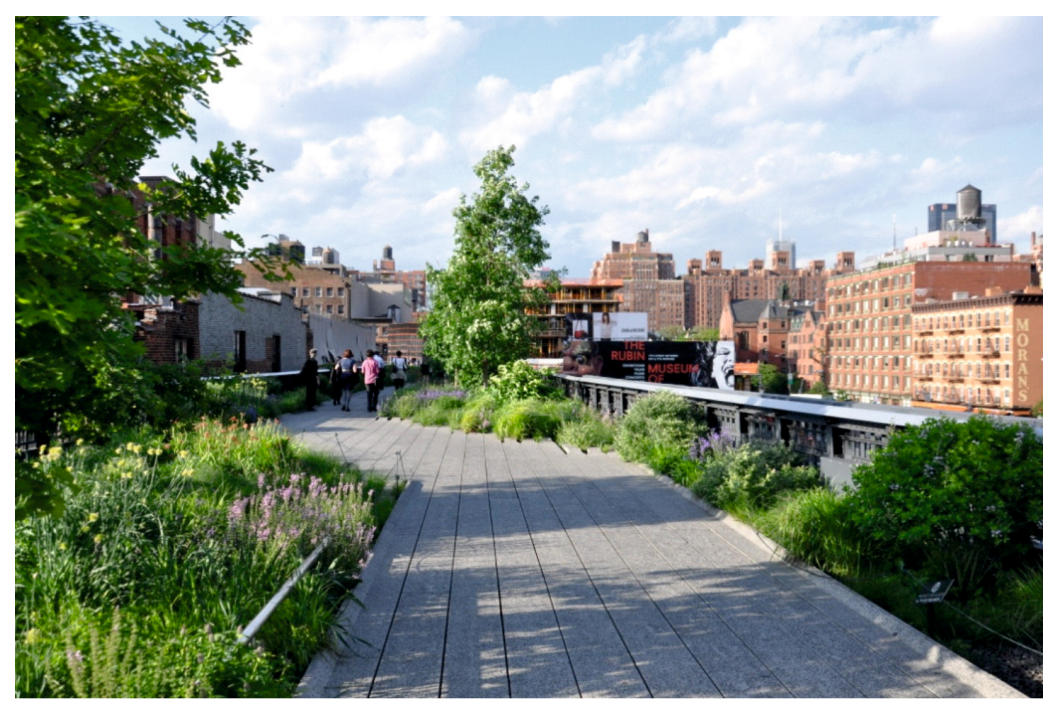

II. 2. High Lane Park w Nowym Jorku (fot. Patrycja Haupt)

III. 2. High Lane Park in New York 


\section{PRZYPISY}

1 T. Jastrząb, Przestrzenie publiczne we współczesnej architekturze i urbanistyce, Wydawnictwo Politechniki Poznańskiej, Poznań 2004, s. 101.

2 K. Pluta, Przestrzenie publiczne miast europejskich. Projektowanie urbanistyczne, Oficyna Wydawnicza Politechniki Warszawskiej, Warszawa 2012.

3 P. Haupt, Nowy Jork - miasto pieszych?, „Środowisko Mieszkaniowe/Housing Environment”, nr 13/2014, s. 61.

4 W. Graham, Miasta wyśnione, Karakter, Kraków 2016, s. 185.

5 Ibidem.

6 E. Kusińska, Woda w założeniach architektoniczno-urbanistycznych, Wydawnictwo Katedry Kształtowania Środowiska Mieszkaniowego, Wydział Architektury Politechniki Krakowskiej, Kraków 2009.

7 H. Dreiseitl, D. Grau, New waterscapes. Planning, Building and Designing with Water, Birkhauser, Basel 2005, s. 140.

8 SUDS - Sustainable Urban Drainage System - zrównoważony system zagospodarowania wody opadowej, polegający na zatrzymaniu wody deszczowej w miejscu opadu i po oczyszczeniu ponowne jej zagospodarowanie do celów użytkowych.

9 P. Haupt, op. cit., s. 64.

${ }^{10}$ https://budzet.krakow.pl/ (dostęp: 01.07.2017).

${ }_{11}$ M. Jagiełło-Kowalczyk, Parki Nowego Jorku. Droga do sukcesu, „Środowisko Mieszkaniowe/ Housing Environment", nr 16/2016, s. 127.

12 Ibidem, s. 129.

13 Ibidem, s. 126.

${ }^{14}$ Artysta z sąsiadami z bloku umówił się, żeby o określonej godzinie zapalili lub zgasili światła w mieszkaniach, aby na elewacji powstał świetlny napis 2000. Była to akcja, która wymagała ścisłego współdziałania wszystkich mieszkańców bloku, a wzięło w niej udział ok. 3000 osób.

15 T. Żylski, Miejscy aktywiści w natarciu, „Architektura”, nr 08/2014, s. 25.

16 Ibidem, s. 22.

17 https://budzet.krakow.pl/ (dostęp: 01.07.2017).

18 http://krakow.wyborcza.pl/krakow/7,44425,21831919,inwestycja-w-zielen-oplaca-sie-i-mieszkancom-i-deweloperom.html (dostęp: 10.07.2017). 


\section{BIBLIOGRAFIA}

Dreiseitl H., Grau D., New waterscapes. Planning, Building and Designing with Water, Birkhauser, Basel 2005, s. 140.

Ewaluacja procesu wdrażania budżetu obywatelskiego w Krakowie. Raport końcowy, Kraków 2016.

Gehl J., Miasta dla ludzi, Wydawnictwo RAM, Kraków 2010.

Graham W., Miasta wyśnione, Karakter, Kraków 2016.

Haupt P., Nowy Jork - miasto pieszych?, „Środowisko Mieszkaniowe/Housing Environment”, nr 13/2014, s. 60-65.

Jagiełło-Kowalczyk M., Parki Nowego Jorku. Droga do sukcesu, „Środowisko Mieszkaniowe/ Housing Environment", nr 16/2016, s. 122-131.

Jak przetworzyć miejsce. Podręcznik kreowania udanych przestrzeni publicznych, praca zbiorowa, Project for Public Spaces Inc., wydanie polskie: Fundacja Partnerstwo dla Środowiska, Kraków.

Jastrząb T., Przestrzenie publiczne we współczesnej architekturze i urbanistyce, Wydawnictwo Politechniki Poznańskiej, Poznań 2004.

Kusińska E., Woda w założeniach architektoniczno-urbanistycznych, Wydawnictwo Katedry Kształtowania Środowiska Mieszkaniowego, Kraków 2009.

Pluta K., Przestrzenie publiczne miast europejskich. Projektowanie urbanistyczne, Oficyna Wydawnicza Politechniki Warszawskiej, Warszawa 2012.

Żylski T., Miejscy aktywiści w natarciu, „Architektura”, nr 08/2014, s. 22-32.

\section{Źródła internetowe:}

https://budzet.krakow.pl/ (dostęp: 1.07.2017).

http://krakow.wyborcza.pl/krakow/7,44425,21831919, inwestycja-w-zielen-oplaca-sie-i-mieszkancom-i-deweloperom.html (dostęp: 10.07.2017).

http://www.thehighline.org/ (dostęp: 1.07.2017). 